RESEARCH ARTICLE

\title{
ANALYSIS OF THE CORRUPTION CHARGE OF THE RICE MANAGEMENT AT GUDANG BULOG BARU RANDUGARUT, SEMARANG REGIONAL SUBDIVISIONS BY 2016-2017 (CASE STUDY OF CONVICT NURUL HUDA)
}

\author{
Irawan $^{1}$, Joko Susanto ${ }^{2}$ \\ lPoliteknik Ilmu Pelayaran Semarang (Navigation Shipping Polytechnic) \\ ${ }^{2}$ Community Movement Against Corruption (GMPK), Semarang \\ $\triangle$ irawan071981@gmail.com
}

\section{CITED AS}

Irawan, I., \& Susanto, J. (2020). Analysis of the Corruption Charge of the Rice Management at Gudang Bulog Baru Randugarut, Semarang Regional Subdivisions by 2016-2017 (Case Study of Convict Nurul Huda). Journal of Law and Legal Reform, 1(2), 279-296. DOI: https://doi.org/10.15294/jllr.vlil.35451

\begin{abstract}
Law enforcement is to realize a sense of justice, legal certainty and usefulness in society. For justice seekers, police and prosecutors 'investigations, as well as quality public prosecutors and judges' decisions can bring about justice or reflect a sense of justice that can be carried out and can be accepted or satisfied by justice seekers. Therefore, through this case study, the writer will invite to see whether there is still a sense of justice, as experienced by convicted corruption cases of Rice Management in the New Bulog Warehouse Randugarut Subdivre Semarang in 2016-2017 named Nurul Huda Bin Sholeh. Even though it was clearly stipulated according to Article 55, Nurul Huda could be classified as included in the offense. But the prosecutor actually demanded Nurul Huda as the sole offender. Whereas Nurul Huda should have the right to obtain the protection of his rights, his equality in the eyes of the law and proportionality in his interests, so that if the burden of accountability for losses in the corruption of GBB Ranndugarut is only charged to him, it will certainly damage the value of justice received.
\end{abstract}

Keywords: Justice, Case Study, Corruption, Bulog, Criminal Law 


\section{TABLE OF CONTENTS}

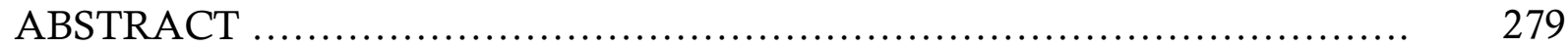

TABLE OF CONTENTS .................................................... 280

INTRODUCTION ....................................................... 280

CORRUPTION CASE OF GBB RANDU GARUT ............................. 282

I. THE CHRONOLOGY IN THE CASE OF GBB RANDU GARUT
CORRUPTION $\ldots \ldots \ldots \ldots \ldots \ldots \ldots \ldots \ldots \ldots \ldots \ldots \ldots \ldots \ldots \ldots \ldots \ldots \ldots \ldots \ldots \ldots \ldots \ldots \ldots \ldots \ldots \ldots \ldots \ldots \ldots \ldots \ldots \ldots \ldots \ldots$

II. THE CASE ANALYSIS ................................................. 285

JUDICIAL SYSTEM FOR CORRUPTION CASES IN INDONESIA .......... 288

THE ROLE OF CORRUPTION COURT JUDGES ........................... 289

CONCLUSION ....................................................... 291

REFERENCES ...................................................... 292

\section{INTRODUCTION}

Main goal of law enforcement is realizing sense of justice, certainty of the law, and expediency in society. Therefore, in conducting process must reflect the aspects of certainty and order of law. Sudikno Mertokusumo defines a criminal as final device or ultimum remedium. Some consider ultimum remedium is one of the principles which is in Indonesian criminal law that says criminal law has to be the last effort in the law enforcement (Sutatiek, 2013). It means if a case can be done through another way, such as kinship, negotiation, mediation, court of justice, or administration law, therefore, those ways should be taken first (Hamzah, 1991; 2010).

In every case investigation and prosecution or adjudication there is a decision that can be accounted not only from certainty of the law (formulation of articles in law) and expediency for some parties, but also must reflect justice and human values. Refer to an opinion of Former Supreme Judge, Bismar Siregar, said that in set his verdict, first a judge pray to Allah SWT, on behalf of His Name a verdict is said. He swears in the Name of The One Almighty God and his heart begins to tremble. So, a judge must qualified where based on the consideration of law according to the facts revealed at the court, in accordance with the judge's beliefs without any influences from various internal and external intervention parties, so it can be accounted professionally to the public (the truth and justice) (Lopa \& Yamin, 2001).

Thus, investigation and prosecution or good verdict must reflect the sense of justice and truth which can bring benefit for the public, nation and state. Moreover, it also must be visionary, so that the case management or its verdicts are not obsolete.

For the justice seekers, police and attorney investigation, public prosecutor and qualified jurisprudence can create justice or reflect sense of justice that can be held, accepted or satisfied them. Investigation, prosecution and qualified verdict exist not only because the finesse and professionalism of the law enforcement and the judge in 
applying law on a case, but also there is a skill to reconstruct justice which exists in the public. Police, attorney, and judge in handling and hearing professional case, is not only an applicant, enforcer, and inventor of the law, but is obliged to predict what will happen after the verdict is handed down (Siregar, 1995).

This is what the convicted corruption of rice management seeks in the new Bulog warehouse Randugarut regional Semarang subdivision by 2016-2017, Nurul Huda Bin Sholeh who is the residents of Cemplorejo VI/7 RT 5/RW 3, Krobokan village, Sub-district of West Semarang, Semarang City, unable to pay personal legal counsel, but a prodeo case counseling. But the first time the suspect who was born on 6 September 1973 was convicted in the register of case number: 102/Pid.SusTPK/2017/PN.Smg, with criminal charges handed down by a joint prosecutor from the public prosecutor at the Central Java High Prosecutor of the City of Semarang, for 6 years reduced during the defendant was in custody in order to the defendant is still detained and sentenced with criminal fine Rp 50.000.000,- (Fifty million Rupiahs) subsidiary 3 (three) months in confinement and dropping punitive money for state deprivation reach Rp. 5.017.309.194,40 (Five billion, Seventeen Million, Three Hundred and Nine Thousand, A Hundred and Ninety Four, comma Forty Rupiahs) subsidiary 3 (three) years in confinement (Mertokusumo, 2009). Unfortunately, in this case, Nurul Huda used to be the sole perpetrator by Attorney General in Central Java with the condemnation by Semarang State Court at the first degree with prison sentences for 4 (four) years, fine about Rp. 50.000 .000 (Fifty million Rupiahs) and paid punitive money for state deprivation reach Rp. 739.667.000 (Seven Hundred and Thirty Nine Million Six Hundred and Sixty Seven Thousand Rupiahs) subsidiary 2 (two) years in confinement.

After the appeal had granted by General Attorney Semarang City from Supreme Court Central Java, then based on the verdict from Supreme Court Central Java Number: 12/Pid.Sus-TPK/2018/PT Smg, the sentence dropped was strengthened, with his demand reinforcing the verdict of the Corruption Court Semarang, which was asked for appeal. Afterwards, the verdict was not stopped there, Imperial Court rate, in October, $30^{\text {th }}$ 2018, the verdict was weighted with the punishment which turned into prison penal for 5 (Five) years and the fine also went up to Rp 200.000.000,(Two Hundred Million Rupiahs), subsidiary 6 (Six) months in confinement, and paid punitive money for state deprivation reach Rp. 739.667 .000 (Seven Hundred and Thirty Nine Million, Six Hundred and Sixty Seven Thousand Rupiah) subsidiary 2 (Two) years in confinement.

In that case, Nurul Huda as a weigh agent GBB Randu Garut felt deprived of justice which he should receive. That was because of the status of the sole suspect which he got, and the responsibility to paid punitive money which he did not enjoy. Whereas, if you look closely in the case, Nurul Huda made hollow staple to fool SPI, so that they did not know if there was a lack about 600 tons result Fiction GD based on his boss instruction.

However, he still became the sole suspect which must bear the whole loss, without any parties which could be asked for responsibility related to the loss of the money that caused state deprivation approximately Rp.5.017.309.194,40 (Five Billion, Seventeen Million, Three Hundred and Nine Thousand, One Hundred and Ninety 
Four, comma Forty Rupiahs). Whereas Nurul Huda was not equal as the chief, he was only common Stated Owned Company employee who graduated from high school and worked as a weigh agent. But, the investigator or public prosecutor in Supreme Court of Central Java and General Attorney of Semarang City do not develop this case or set new suspect until now.

From this, this writing will consider further about the value of justice which Nurul Huda, the convicted of the GBB Randu Garut Corruption Case with state deprivation reach Rp. 5.017.309.194,40 (Five Billion, Seventeen Million, Three Hundred and Nine Thousand, One Hundred and Ninety Four comma Forty Rupiahs), deserves.

This paper examines and analyzes two main point, first, how could the Corruption Case of Rice Management at Gudang Bulog Baru Randu Garut, Semarang Regional Subdivision by 2016-2017 which caused state deprivation reach Rp.5.017.309.194,40 be handled? And second, how does the value of the justice which gained by the convict Nurul Huda at that case?

\section{CORRUPTION CASE OF GBB RANDU GARUT I. THE CHRONOLOGY IN THE CASE OF GBB RANDU GARUT CORRUPTION}

GBB Corruption began with an invention of hollow in the stacks of staple at the warehouse when the rice distribution process in GBB Randu Garut to GBB Harjosari Bawen Semarang District in June $19^{\text {th }}-20^{\text {th }} 2017$ was going on. With that invention, this case was followed up with a formation of GBB Randu Garut Semarang Regional Subdivision Stock Opname Team to calculate the stock commodity of rice and other staples which are managed both physical and administrative toward the allegation of the shortage of rice commodity stock at GBB Randu Garut. The team of GBB Randu Garut Stock reported that there was a gap in size about 697.653,83 kilograms or 697 tons.

In that case, Nurul Huda as a weigh agent at GBB Randu Garut based on Perum Bulog Directors' Decree Number : KD-61/DS102/03/2012 in March, $9^{\text {th }} 2012$ has a job to do balancing, logging, accounting in and out of Perum Bulog commodities, also observing and testing the accuracy of weigh tool, and help the warehouse chief in terms of income, storage, management, maintenance, and outcome of Perum Bulog commodity, based on Perum Bulog Directors' Decree Number : PD-11/DS200/03/2017 in March, 24 2017 about The Organization and Labor of the Regional Division Bulog Section 77 verse 2 which become the basis for the case of 600 tons rice disappearance from GBB Randu Garut.

This case started when there was an appropriate rice perception between the quantum amount of rice listed in the Warrant Receives Item with the amount of quantum rice that GBB of Randu Garut accepted. With this inappropriate condition in the Warrant Receives Item with the real which Randu Garut GBB accepted, Nurul 
Huda reported to Hosdianto. Hosdianto was the head of the GBB Randu Garut Warehouse. He said that he would handle that problem and ask Nurul Huda to make weigh receipt according to the amount of quantum rice listed in the Warrant Receives Item and inappropriate condition that Randu Garut GBB received. Although it was causing a lack on the rice supplies at Randu Garut GBB.

To offset the lack of the rice supplies and to anticipate the inspection from Internal Supervisor Unit Bulog toward the rice supplies in the warehouse, thus it needed to unpack the staple stacks, so that Internal Supervisor Unit could not see the lack. Nurul Huda with a notice from Hosdianto did the unpacking process every 6 month and needed someone outside the warehouse to help him. To pay the worker who helped him, he took out the rice from GBB Randu Garut Warehouse as the order from Hosdianto without looked at the Unload Warrant/Delivery Order where the money of the rice spent outside the Unload Warrant/Delivery Order was used to covered up the operational cost of unpacking staple process, and the rest of it was used by Hosdionto for personal need. Nurul Huda had suggested Hosdianto to report the rice supplies to Semarang Regional Subdivision, but Hosdianto refused it and calmed his down that it would be his responsibility. Until he was transferred to be the head of Tambak Aji GBB, the lack of the supplies were never been replaced.

When the turn of the head of the GBB Randu Garut Warehouse from Hosdianto to Budiawan Hendratno, have done some checking on the rice storage both physically and administratively (stock opname) by the Stock Opname Team which formed by Regional Division and recorded at the time of examination in October, $8^{\text {th }} 2015$ was available 200.677 bale/4.417.155,90 kilograms. But, in that examination was not be done entirely because it was done by counting the length times the width of the foot times the height of the foot times 5 (because it is locked 5) so that the staple hollow was unseen. Even though Hosdianto was transferred to be the head of Tambak Aji GBB, the lack of the rice supplies was still not replaced. Within 2016 until the middle of June 2017, Nurul Huda persisted the process of taking out the rice from Randu Garut GBB without looked at the Unload Warrant/Delivery Order by order of Budiawan Hendratno where the money was used both to covered up the operational cost of unpacking staple process and to anticipate if there was an examination from Internal Supervisor Unit to Randu Garut GBB. As a result, the lack of rice supplies was increased to 697 tons.

In the process of taking out the rice without looked at the Unload Warrant/Delivery Order, Nurul Huda asked the worker named Abu Tolib, Edi Suprapto, and Teguh Setiono to come to Randu Garut GBB at the specific time which usually outside of work hours after 8 p.m. or on Weekend, he also decided which rice stack would be taken out and which staple would be arranged. After the rice was taken out from the warehouse, the stacks in the hollow staple were arranged with flonder or wooden crutches which put inside the stacks with the position of the flonder is vertical and horizontal, so, the rice can be put on it. Thus, the staple looks full, though it is empty inside. If the vertical flonder is unexpected, Nurul Huda would put some stacks of rice below based on the need.

Then, the rice which taken out from the warehouse was loaded in the pickup car L-300 and Rusno's Kijang where the rice purchased in cash from Nurul Huda and 
priced RP. 6.000; s/d Rp. 6.300;- per kilos. Nurul Huda's decision as the weigh agent who taken out the rice supplies from Randu Garut GBB without looked at the Unload Warrant/Delivery Order and had arranged the rice stacks inside the hollow staple in GBB Randu Garut Warehouse has been contradicted with:

1. Perum Bulog Directors' Decree Number: KD-107/DO301/03/2009 in March 24 ${ }^{\text {th }}$ 2009 about Warehouse Laws in Perum Bulog Environment section 6 about commodity handover:

a) Commodity handover in the warehouse is based on Unload Warrant/Delivery Order which has been signed by the head of Regional Division/ the head of Regional Subdivision/ the head of Logistic Department/ another functionally who is authoritative;

b) The amount of weight, type, quality, commodity parties which are handed must fit with the amount which is noted in the Unload Warranty/Delivery Order;

c) The transition of responsibility on the commodities which are handed from the head of the warehouse/ the warehouse clerk to the party which accepts it after the weigh-in process must be proved with signing the handover document by the head of the warehouse who receives the item;

d) The handover of the commodities in the warehouse is noted consist of the number of bales, gross weight, and net weight, which are administrated and reported according to the Standard Operating of Administration and Accountability Report of Commodity which are inseparable attachment from this decision.

2. Perum Bulog Directors' Decree Number: PD-19/DO100/06/2017 in June $16^{\text {th }} 2017$ about Warehouse Management section 12 about the Commodity Handover verse 1 where the Unload item and handover item in the warehouse based on the Unload Warranty/Delivery Order.

3. Perum Bulog Directors' Decree Number: SOP-25/DO301/03/2009 in March, $24^{\text {th }}$ 2009 about to the Standard Operating of Storage Item at Perum Bulog, roman numerals V: in committing the Perum Bulog commodity saving, must be regulated in some ways according to the item's characteristic which is kept so that it doesn't make another lack on the item or another item inside the warehouse. Besides, every stack must consist of the same bales, and there must a strong flonder below the stacks which are arranged well for good circulations mainly from below. In order to make the stacks which are saved in the warehouse strong enough, won't come down easy, and countable, so, the arrange system must be regulated with lock system combination of 5,7,8 locked bricks.

The consequences of Nurul Huda, Hosdianto, and Budiawan Hendratno's actions in abusing their authority, chance, or facility which are belong to their position caused financial loss for the state reached 697 tons which accumulated into Rupiah that is equivalent to Rp. 5.017..309.194,40 (Five billion, Seventeen Million, Three Hundred and Nine Thousand A Hundred and Ninety Four, comma Forty Rupiahs), which is suitable with Audit Report in order to Count the Losses of the State on suspicion of Criminal Corruption on Rice Management in Randugarut GBB, 
Semarang Regional Subdivision by 2016-2017 from Indonesian Supreme Audit Institution Central Java deputation.

Whereas in the verdict of the case start from the first degree of Semarang District Court to the cassation of Supreme Court, Nurul Huda was considered by the Council legally and surely guilty in doing Criminal Corruption together, as set and threaten in Section 3 Jo Section 18 Act of the Republic Of Indonesia Number 31 in 1991 about Against Corruption Charges, as altered and augmented with Act of the Republic Of Indonesia Number 20 in 2001 about the transformation of the First Act of the Republic Of Indonesia Number 31 in 1991 about Against Corruption Charges Jo Section 55 verse 1 Criminal Code, as the Public Prosecutor's subsidiary indictment.

\section{THE CASE ANALYSIS}

Nurul Huda was become the sole perpetrator in the Randugarut GBB corruption, then convicted for 5 (five) years in confinement, imposed to pay the fine Rp 200.000.000,(Two Hundred Million Rupiahs) subsidiary 6 (six) months in confinement, and paid punitive money for state deprivation reach Rp. 739.667.000 (Seven Hundred and Thirty Nine Million, Six Hundred and Sixty Seven Thousand Rupiahs) subsidiary 2 (two) years in confinement are worthwhile question. Consider of every action that had been prosecuted to him were the order from his boss, Hosdianto and Budiawan Hendratno.

In 2014, when Randugarut GBB was conducted by Hosdianto, the position of rice supplies had had lack which caused by Fiction GD. Nurul Huda was asked by Hosdianto to write the quantum of rice down as in the Warrant Receives Item and in unreal condition that Randu Garut GBB received. That is the beginning of the lack of the rice supply in Randugarut GBB which reached 400 tons.

To cover up the lack of the rice supplies and to anticipate the inspection from Internal Supervisor Unit Bulog toward the rice supplies in the warehouse, Nurul Huda was asked to make a hollow staple because the counting is only seen visually, like on the key of 5 times length times width times height.

To make that hollow staple needs some costs to pay the worker, then the costs, below Hosdianto's instruction, Nurul Huda was asked to taken the rice out from Randugarut GBB without looked at the Unload Warrant/Delivery Order, then it was sold to Rusno, a retired from Bulog. The money of the rice was used to pay the operational cost of staple making process, and the rest of it was given Hosdianto for personal need.

After that, when the turn of the head of the Warehouse from Hosdianto to Budiawan Hendratno, the physical stock was still in-appropriate and it was known by both of them. When Budiawan Hendratno conducted the warehouse, every time there was a distribution, the hollow staple was seen. Then, he asked Nurul Huda to make new hollow in another staple. It was the same as before that the making of the hollow needed some costs for tearing down and reforming the staple, so the cost problem repeated on taking the rice out without looked at the Unload Warrant/Delivery Order. 
In that case, Hosdianto and Budiawan Hendratno's status never upgraded became the suspect and it was only Nurul Huda who became the sole perpetrator. That was became an objection because Nurul Huda only executed his boss' order, and responsible for the loss of 697 tons or Rp. 5.017.309.194,40 (Five billion, Seventeen Million, Three Hundred and Nine Thousand, A Hundred and Ninety Four, comma Forty Rupiahs). It is true that Nurul Huda can be accounted for the lack of the rice supplies, but he is not the only one. The boss who gave him an order also had the responsibility for the lack that was happened.

Start from Directors' Decree Number: KD 107 Chapter IV Section 10 verse 1 that if happen a warehouse shortage which caused by decreasing, lacking/losing, breaking of the commodities which are saved in warehouse, then, the head of the warehouse, office clerk, and weigh agent can be accused for compensation demands. At verse 2 then there is an exception in the rule of section 10 verse 1 if:

1. The head of the warehouse, office clerk, and weigh agent, each personally can prove that the loss was not their fault or their neglect;

2. The loss is caused by the condition of Force Majeure (like earthquake, landslide, flood, wildfire or other possibilities beyond the clerk ability);

3. And the last natural decrease which is not beyond the toleration limit.

At the Chapter V Section 11 verse 1 explains that the head of Regional Division/ the head of Regional Subdivision/ the head of Logistic Department, the head of the warehouse, and the warehouse clerk must conduct every activities of the item management to prevent the loss appears. In fulfill the corruption charges as mentioned in the Section 3 verse 1 Jo Section 18 Act of the Republic Of Indonesia Number 31 in 1991 about Against Corruption Charges, as altered and augmented with Act of the Republic Of Indonesia Number 20 in 2001 about the transformation of the First Act of the Republic Of Indonesia Number 31 in 1991 about Against Corruption Charges will face some factors, such as:

a. To benefit oneself or others or corporation;

b. Abusing the authority or facility which exist because of his/her position;

c. Disserve country financial or economy.

In that case, what prosper mean is same with gain profit, that is earn bigger than the outcome, regardless of the further use of the acquired income. This trait of against the law has been exist in other elements, important element or main part from offence's core which must be defined or given a boundary by the law to prevent interpretation differences in applying section 3. That is the third element in this practice needs justification from the Constitutional Law and Public Administration (Mustamu, 2014). Then the case of Nurul Huda was proved that some took benefit for themselves or others in a corporation.

In abusing the authority, chance, and facility because the position was fulfilled. In Directors' Decree Number: KD 107 Chapter IV Section 10 verse 1 that if happen a warehouse shortage which caused by decreasing, lacking/losing, breaking of the commodities which are saved in warehouse, then, the head of the warehouse, office clerk, and weigh agent can be accused for compensation demands. 
In this case, not only Nurul Huda who was the clerk that can be accounted, but also Hosdianto and Budiawan Hendratno as the head of the GBB Randugarut warehouse on the loss of state deprivation reach Rp. 5.017.309.194,40 (Five billion, Seventeen Million, Three Hundred and Nine Thousand, A Hundred and Ninety Four, comma Forty Rupiahs). However, the verdict until the degree of cassation in Supreme Court in October, 30 ${ }^{\text {th }} 2018$, just incriminate with charges which verdict from 4 (Four) years to 5 (Five) years in confinement, and the fine increased to $\mathrm{Rp}$ 200.000.000,- (Two Hundred Million rupiahs), subsidiary 6 (Six) months in confinement, and paid punitive money for state deprivation reach Rp. 739.667.000 (Seven Hundred and Thirty Nine Million, Six Hundred and Sixty Seven Thousand Rupiahs) subsidiary 2 (two) years in confinement.

It did not feel fair for Nurul Huda, because he considered that in the deed, his boss, Hosdianto, had a more important role in the state deprivation. However, Hosdianto had never been examined as a suspect of corruption cases of Randugarut GBB until he died, also Budiawan Hendratno because of his status had never been going up.

It is clear that the serve which was assumed it was proven on Nurul Huda, that was found guilty and assured until cassation grade in Supreme Court, against Section 3 Jo Section 18 Act of the Republic Of Indonesia Number 31 in 1991 about Against Corruption Charges, as altered and augmented with Act of the Republic Of Indonesia Number 20 in 2001 about the transformation of the First Act of the Republic Of Indonesia Number 31 in 1991 about Against Corruption Charges Jo Section 55 verse 1 Criminal Code, as the Prosecutor's subsidiary indictment.

Regarding the inclusion regulation in doing criminal offense are found in Section 55 and 56 Criminal Code. In that regulation, we can conclude that between the person who ordered and the person who do the order of criminal offense is being categorized as the Criminals. According to Van Hammel in Lamintang, which taught a theory about inclusion as a general theory, primarily is a theory about responsibilities, in which an offence that according to the legislation, actually can be done by two people or more in a good corporation physically (intellectual) or materially (Sukmawati, 2016).

Whereas, when we look at the existing file, Hosdianto and Budiawan Hendratno, when the physical examination of the rice supplies in October, $8^{\text {th }} 2015$, then signed by Randugarut GBB Officers (Nurul Huda, Hening Saptiwi, Dwi Rizki Sukma), agreed that Hosdianto (The head of Randugarut GBB), Stock Opname Team (Ramelan M, Nurjuliansayah Rachman, and Suudi Mutim), and known by Musazdlin Said as the Regional Vice Chief, which in the reality, examination of rice supplies on that date was not be done entirely, but only with counting the length times width times height (Locked 5) where it was locked 5 because the rice was arranged, there was an intervention from Hosdianto and Budiawan Hendratno.

So that when it is studied based on Section 55, Nurul Huda could be categorized into the criminal offence. But, we need to know that Section 55 explains about what the participated person (medepleger) is, according to $\mathrm{R}$. Soesilo, "contributing" in "doing together" is unless there are 2 persons who doing (pleger) and 
contributing (medepleger) into the criminal offense (Ulfa, Din, \& Dahlan, 2017). Whereas, is that case, both of them was doing the criminal deed. It is forbidden if someone's only doing the preparation, or only helping, because those who help is not belong to the medepleger, but they belong to "the helper" (medeplichtige) in Section 56 Criminal Code.

So that the prosecution attorney who prosecute Nurul Huda as the sole perpetrator that fulfill Section 55 could not be done. It remains that inside the Section 55, there must be two persons who do pleger and also do medepleger. Nurul Huda in doing the Criminal Corruption Case which caused the loss of state deprivation reach Rp. 5.017.309.194,40 (Five billion, Seventeen Million, Three Hundred and Nine Thousand, A Hundred and Ninety Four comma Forty Rupiahs) did not do it himself, but he did that together with his bosses, Hosdianto and Budiawan Handratno.

Therefore, Supreme Court cassation which made Nurul Huda as the sole perpetrator, absolutely did not give a sense of justice for Nurul Huda. Because, according to Mahfud MD, reflection of justice in the main element, the fundamental and the most abstract because it is a concept of justice, it contains protection of rights, equality in the law position, also principals of proportionality to individual interests, social and state interests (Mahfud MD, 2009). Because Nurul Huda has his rights, which are protection of rights, equality in the law position, and principals of proportionality to his interests, so when the responsibility of the loss of state deprivation in GBB corruption case just imposed to him, it will injure the sense of justice which he got.

\section{JUDICIAL SYSTEM FOR CORRUPTION CASES IN INDONESIA}

The justice system in Indonesia is inseparable from the existing legal system in this country, because only the law is able to regulate that the justice system follows which direction it adheres to the law enforcement process. Based on the opinion of Bachsan Mustafa (2003: 5-6) states that "The system as a type of unit that is built with the components of the system that is related mechanically functional to one another to achieve goals, the legal system consists of components of the soul of the nation, structural components, components of substance, and components of legal culture ". The Indonesian judicial system can be interpreted as an orderly and interrelated arrangement relating to the examination and termination activities of a court, whether it is a court within the General Courts, Religious Courts, Military Courts, or State Administrative Courts, based on by the views, theories, and principles in the field of justice prevailing in Indonesia.

According to Eric L. Richard in Suherman (2004) argues that "The justice system in each country is influenced by the legal system adopted by the State, the main legal system in the world (The World's Major Legal Systems) can be divided into: civil law; common law; Islamic law; socialist law; sub-Saharan Africa; and Far 
East". In general, it can be said that the institutional configuration of 'judging' functions in this day and age is indeed undergoing very dynamic changes and developments. "Our justice system in Indonesia is undergoing a process of structural differentiation, decentralization, deconcentration, and even institutional deconstruction that is very widespread" (Asshiddiqie, 2013: 2).

The dynamics of such structural developments may not be immediately well organized and stable in the near future, because new ideas about special justice continue to develop among experts and legal observers through various mass media.

The task burden of judicial institutions in the conventional sense today can be said to be experiencing solid functional development, so there is an awareness of the importance of reorganizing judicial functions by separating or carrying out decentralization or deconcentration by establishing a dispute resolution mechanism outside the court (out of court settlement). With this mechanism in place, the legal settlement process is not always idealized to be completed in and through the court (in-court settlement) but can also be completed through out of court settlement. Therefore, the legal and judicial system is considered important to be equipped with mediation procedures, arbitration, and even peace judges (Asshiddiqie, 2013: 1-2).

\begin{abstract}
"Simply put, the judicial process in Indonesia can be grouped into three stages, namely the preliminary stage, the determination and implementation of decisions" (Santoso, 2011: 37). Looking at the judicial process in Indonesia, there are several points that must be supervised, namely in the process of executing decisions by the court, because therein lies the authority of a law enforcer in the enforcement of the judicial process in Indonesia, if it can be guarded and taken seriously for several years. going forward will be a clean and authoritative court in this country.
\end{abstract}

The ideal norm system, both in the field of law and ethics, in contemporary life is developing very complex, and deviations against it can no longer be handled and corrected only by a centralized justice system and concentrated in one institutional system. In fact, the dispute settlement functions that were initially considered sufficient to be resolved by the judiciary are considered to be inadequate, resulting in ideas about 'out of court settlement' in addition to the usual 'in-court settlement' mechanism (Asshiddiqie, 2013: 13).

The function of the judiciary in resolving disputes in accordance with justice is highly expected by the public for the creation of legal certainty in this country, for this reason the judiciary is expected to exist in upholding the law.

\title{
THE ROLE OF CORRUPTION COURT JUDGES
}

One of the problems that will always be faced by judges is how they can make a good court decision so that it can meet the legal values and a sense of community justice. Theoretically, it is realized that court decisions are not mere legal products, at a 
certain level court decisions that "amputate" the norms of colonial heritage can be more important than the laws and regulations. Therefore, if there are legislation or political policies that are discriminatory and hinder the welfare of the people, the court as the organizer of an independent and independent judicial authority must have the courage to override or invalidate the rule of law and prioritize the welfare of the community in order to achieve the goals of the Government of the Republic of Indonesia, to improve the function and role of court decisions in order to balance the function and role of laws and regulations in realizing the welfare of the people, the guarantee of the independence and independence of judges to determine the mindset and attitude of actions in the construction of a court decision is very important. A judge must have a role colored by three conditions, namely:

a. Resilient, resilient in dealing with circumstances and mentally strong.

b. Skilled, it means knowing and mastering all existing and still applicable laws and regulations.

c. Responsive, meaning that the completion of the case inspection must be done quickly, correctly, and adjust to the wishes of the community (Supriadi, 2008: 118).

The basic principle that must be owned by a judge in order to carry out the duties of judicial power as well as possible. With the provision of a dissenting opinion mechanism in a court decision regulated in Law Number 4 of 2004 concerning Judicial Power, Law Number 5 of 2004 concerning amendments to Law Number 14 of 1985 concerning the Supreme Court, and Supreme Court Regulations Republic of Indonesia Number 2 of 2000 concerning the improvement of Supreme Court regulations Number 3 of 1999 concerning ad hoc judges, this is a progressive step in the implementation of judicial power in Indonesia where the sovereignty of judges in a court decision that was once collective and closed is now individualized and open to increase transparency and professionalism in the implementation of judicial power in Indonesia. Differences of opinion are a necessity and are human in nature, so differences in mindset and attitudes of members of the panel of judges in constructing a court decision are also conditio sine qua non. The role of Corruption Court judges is actually already contained in the Act, so every act carried out by a judge is regulated in the Act.

Article 10 of Law Number 46 of 2009 provides the understanding that "In examining, adjudicating and adjudicating cases of corruption, the Corruption Court, High Court and Supreme Court consist of Career and Ad hoc Judges".

Judges and their obligations as implied in Article 5 paragraph (1) of Law Number 48 of 2009 are as' sense of justice of the people ". Judges as law enforcement and justice explore, follow and understand the legal values that live in This means that to carry out this role, the judge must jump into the community to recognize, feel and be able to explore the feelings of law and a sense of justice that lives in the community, thus the judge can make decisions in accordance with the law and sense of justice of the community.

The task of judges is not only as law enforcers on cases in court or agents of conflict', but it should also include finding and reforming the law. The ideal judge, besides having high intelligence, must also have a sensitivity to values - the value of 
justice, being able to integrate positive law into religious values, decency, manners and customs that live in society through every decision he makes, because in essence, a judge's crown is not on his head, but on the weight or quality of The resulting decision The implementation of the Judge's role as a major component of the judiciary, as well as being a strategic and central part of the judicial authority, besides contributing in carrying out its institutional mission, is also a contributor in the process of public service in upholding law, justice and truth. Others, will also have real implications for meeting responsibilities the institutional responsibility of the judicial authority, the more quality the decisions it produces, the role of the judiciary will be increasingly felt the contribution and benefits for society, nation and state. In Article 11 of Law No. 48 of 2009 concerning Judicial Power stated:

a. The court examines, hears, and decides cases with a composition of at least 3 (three) judges, unless the law stipulates otherwise.

b. The composition of judges as referred to in paragraph (1) consists of a presiding judge and two member judges. (Article 11 paragraph (1) and (2) of Law No. 48 of 2009)

In conducting the judicial process of cases of corruption in the Corruption Court, the examination of the case is carried out by a panel of judges totaling 5 (five) people consisting of 2 (two) District Court judges and 3 (three) Ad hoc judges. With 3 (three) Ad hoc judges in the Corruption Court panel of judges, this shows that there is a political will from the government to increase public participation (parties outside the court) in the judicial process of corruption cases. Increasing community participation (parties outside the court) in the judicial process of cases of corruption is aimed at balancing the mindset and attitude of career judges who are generally assumed to have been "controlled" by positivistic paradigms in examining, judging and deciding a case for conducting justice to uphold law and justice.

The positivistic paradigm generally gives birth to the flow of legism, where judges are only seen as "trumpets of the Act" (bouchede la loi) so that judges are strictly prohibited from making decisions other than based on the Law. The flow of legism has mastered the mindset and attitude of the majority of judges in Indonesia even since the days of the Dutch East Indies. Even though there are only a handful of judges who are "brave" out of the mainstream of the flow of legism who master the mindset and attitude of the majority of judges in Indonesia in constructing a court decision.

\section{CONCLUSION}

In the Randugarut GBB Corruption case which caused the loss of state deprivation reach Rp. 5.017.309.194,40 (Five billion, Seventeen Million, Three Hundred and Nine Thousand, A Hundred and Ninety Four, comma Forty Rupiahs), there should be some parties who contributed in that criminal corruption. But, in the reality, it just Nurul Huda who was a clerk or weight agent, who became the sole perpetrator in that case, so that he must endure the responsibility 5 (Five) years in confinement, and the fine increased to Rp 200.000.000,- (Two Hundred Million rupiahs), subsidiary 6 (Six) months in confinement, and paid punitive money for state deprivation reach Rp. 
739.667.000 (Seven Hundred and Thirty Nine Million, Six Hundred and Sixty Seven Thousand Rupiahs) subsidiary 2 (two) years in confinement.

If we look further the deed of corruption case which was done by Nurul Huda as the order from Hosdianto anf Budiawan Hendratno as the head of Randugarut GBB warehouse which caused a big lack of supplies reached 697 tons. It also had been proved in the judgment. But, why Hosdianto and Budiawan Hendratno had never been examined as a suspect, and it only took Nurul Huda as the sole perpetrator.

The other contrast was in a applying Section 55 Criminal Code, but the fact was still the sole perpetrator. In the Section 55 explains about what the participated person (medepleger) is, according to R. Soesilo, "contributing" in "doing together" is unless there are 2 persons who doing (pleger) and contributing (medepleger) into the criminal offense. Here, both of them was doing the criminal deed. It is forbidden if someone's only doing the preparation, or only helping, because those who help is not belong to the medepleger, but they belong to "the helper" (medeplichtige) in Section 56 Criminal Code. So that the prosecution attorney who prosecute Nurul Huda as the sole perpetrator that fulfill Section 55 Criminal Code could not be considered illegitimate because at least there are two persons who did and contributed.

In that case, there should be other suspect who were appointed and examined, so that the loss of state deprivation not only be imposed to Nurul Huda, but also to the other suspects who were considered had a bigger role and gained bigger benefit in Randugarut GBB corruption case.

From this paper, it is suggested that law enforcement officers, especially the attorney, do not convict the suspect easily, if the evidence is not complete and cannot fulfill the sense of justice yet. Law enforcement officers, especially the attorney do not sacrifice a suspect who is a marginal parties without including the main functionaries. The main goal of law enforcement is to create sense of justice, certainty of the law, and expediency in society. So that in the handling process must reflect the aspects of certainty and order of law. Law enforcement officers should be a accustomed the concept of ultimum remedium, which is the one of principle found in Indonesian Criminal Law. Therefore, the criminal law must be the last effort in the law enforcement. It means when a case could be done in another way, such as kinship, negotiation, mediation, court of justice, or administration law.

\section{REFERENCES}

Audit Report of the Financial and Development Supervisory Agency (BPKP) of Central Java Representative, dated November 3, 2017, in the context of Calculating State Financial Losses on Allegations of Corruption of Rice Management in Randugarut GBB, Subdivre Semarang 2016-2017, Laporan Hasil Audit Badan Pengawasan Keuangan dan Pembangunan (BPKP) Perwakilan Jateng, tanggal 3 November 2017, dalam rangka Penghitungan Kerugian Keuangan Negara atas Dugaan Tipikor Pengelolaan Beras Pada GBB Randugarut, Subdivre Semarang tahun 2016-2017. 
Bassar. S. (1984). Tindak Pidana Tertentu di Dalam KUHP. Bandung: CV Remaja Karya.

Central Java Prosecutor's Investigation, Number: Print-1336/0.3/Fd.1/09/2017, September 5, 2017, concerning Allegations of Corruption that ensnared Nurul Huda, Penyidikan Kejati Jateng, Nomor: Print-1336/0.3/Fd.1/09/2017, tanggal 5 September 2017, tentang Dugaan Tipikor yang menjerat Nurul Huda.

Decision of Central Java High Court, Case Number: 12/Pid-Sus-TPK/2018/PT Smg, dated May 25, 2018, concerning Decision on Case Appeal Rate on behalf of Defendant Nurul Huda, Putusan Pengadilan Tinggi Jateng, Nomor Perkara: 12/Pid-SusTPK/2018/PT Smg, tanggal 25Mei 2018, tentang Putusan Tingkat Banding Perkara Atas Nama Terdakwa Nurul Huda.

Decision of the Supreme Court, dated 30 October 2018, concerning the Decision on the Case of Cassation in the Name of Nurul Huda, Putusan Mahkamah Agung, tertanggal 30 Oktober 2018, tentang Putusan Tingkat Kasasi Perkara atas Nama Nurul Huda.

Decree of the Board of Directors of Perum Bulog, Number. KD-107/DO301/03/2009, dated March 24, 2009 concerning Regulation of Warehousing in the State Logistics Agency Bulog, Surat Keputusan Direksi Perum Bulog, Nomor. KD107/DO301/03/2009, tanggal 24 Maret 2009 tentang Peraturan Pergudangan di Lingkungan Perum Bulog.

Decree of the Board of Directors of Perum Bulog, Number: KD-61 / DS102 / 03/2012, dated 9 March 2012, concerning the Appointment of Nurul Huda as GBB Randugarut Weigher, Subdivre Semarang, Surat Keputusan Direksi Perum Bulog, Nomor: KD-61/DS102/03/2012, tanggal 9 Maret 2012, tentang Pengangkatan Nurul Huda sebagai juru timbang GBB Randugarut, Subdivre Semarang.

Effendi, E. (2014). Hukum Pidana Indonesia (Suatu Pengantar). Bandung: PT. Refika Aditama.

Hamzah, A. (1991). Perkembangan Hukum Pidana Khusus. Jakarta: Rineka cipta.

Hamzah, A. (2010). Asas-asas Hukum Pidana. Jakarta: Rineka Cipta.

Hartanti, E. (2005). Tindak Pidana Korupsi. Jakarta: Sinar Grafika.

Letter of the Head of Central Java Regional Division, Number: SK-13/11030/12/2017, dated December 7, 2017, concerning the Imposition of Indemnity for the Head of the Central Java Regional Division, Surat Kepala Divisi Regional Jateng, Nomor: SK-13/11030/12/2017, tanggal 7 Desember 2017, tentang Pembebanan Ganti Rugi Kepala Divisi Regional Jawa Tengah.

Lopa, B., \& Yamin, M. (2001). Undang-Undang Pemberantasan Tindak Pidana Korupsi. Bandung: Alumni.

Mahfud MD. (2009). Penegakan Hukum dan Tata kelola Pemerintahan Yang Baik. Jakrta: Seminar Nasional.

Siregar, B. (1995). Hukum Hakim dan Keadilan Tuhan. Jakarta: Gema Insani Press.

Prinst, D. (2002). Pemberantasan TindakPidana Korupsi. Bandung: Citra Aditya Bakti.

Rahardjo, S. (1986). Hukum dan Masyarakat. Bandung: Angkasa.

Rahardjo, S. (1981). Pengantar Penelitian Hukum. Jakarta: Universitas Indonesia. 
Sutatiek, S. (2013). Menyoal Akuntabilitas Moral Hukum Pidana dalam Memeriksa, Mengadili dan Memutus Perkara. Yogyakarta: Aswaja Pressindo.

Mertokusumo, S. (2009). Penemuan Hukum Sebuah Pengantar. Yogyakarta: Liberty.

Mustamu, J. (2014). Pertanggungjawaban Hukum Pemerintah (Kajian tentang Ruang Lingkup dan Hubungan dengan Diskresi). Jurnal Sasi, 20(2), 21-27.

Nurul Huda's Personal Defense at the Trial, August 29, 2017, about the Chronology of Rice Loss at GBB Randugarut, Pembelaan Pribadi Nurul Huda di Persidangan, tanggal 29 Agustus 2017, tentang Kronologis Kehilangan Beras di GBB Randugarut.

Republic of Indonesia. (2017). Decree of the Board of Directors of a public company (Perum) Bulog, Number: KD-324 / DS103 / 11/2017, dated November 21, 2017, concerning the Dismissal of the Board of Directors of a Public Company (Perum) Bulog, Keputusan Direksi Perusahaan Umum (Perum) Bulog, Nomor: KD324/DS103/11/2017, tanggal 21 November 2017 tentang Pemberhentian Sementara Direksi Perusahaan Umum (Perum) Bulog.

Republic of Indonesia. (2009). Decree of the Board of Directors of Perum Bulog, Number: SOP-25/DO301/03/2009, March 24, 2009, concerning Standard Operating Procedures for the Storage of Bulog Goods, Keputusan Direksi Perum Bulog, Nomor: SOP-25/DO301/03/2009, tanggal 24 Maret 2009, tentang Standar Operasional Prosedur Penyimpanan Barang Perum Bulog.

Republic of Indonesia. (2017). Decree of the Head of Central Java Regional Division, Number: SK-07/11030/10/2017, dated October 12, 2017, concerning the Imposition of Compensation Claims for the Head of Central Java Regional Division, Keputusan Kepala Divisi Regional Jateng, Nomor: SK-07/11030/10/2017, tanggal 12 Oktober 2017, tentang Pembebanan Tuntutan Ganti Rugi Kepala Divisi Regional Jateng.

Republic of Indonesia. (2017). Peraturan Direksi Perum Bulog, Nomor: PD11/DS200/03/2017, tanggal 24 Maret 2017 tentang Organisasi dan Tata Kerja Perusahaan Umum Bulog Devsisi Regional.

Republic of Indonesia. (2017). Peraturan Direksi Perum Bulog, Nomor: PD19/DO100/06/2017 tanggal 16 Juni 2017, tentang Manajemen Pergudangan di Lingkungan Perum Bulog.

Republic of Indonesia. (1999). Republic of Indonesia Law No. 31/1999 concerning Eradication of Corruption, as amended and supplemented with RI Law No. 20/2001 concerning amendments to RI Law No. 31/1999 concerning Eradication of Corruption, Undang-Undang RI Nomor 31 tahun 1999 tentang Pemberantasan Tindak Pidana Korupsi, sebagaimana telah diubah dan ditambah dengan UU RI Nomor 20 Tahun 2001 tentang perubahan atas UU RI Nomor 31 tahun 1999 tentang Pemberantasan Tindak Pidana Korupsi.

Semarang District Court's Decision, Case Number: 102/Pid-Sus-TPK/2017/PN-Smg, March 19, 2018, concerning the Decision on the First Level Case on the Defendant's Name Nurul Huda, Putusan Pengadilan Negeri Semarang, Nomor Perkara: 
102/Pid-Sus-TPK/2017/PN-Smg, tanggal 19 Maret 2018, tentang Putusan Tingkat Pertama Perkara Atas Nama Terdakwa Nurul Huda.

Sukmawati, S. (2016). Turut Serta Melakukan Perbuatan Pidana Menurut Kitab Undang-Undanghukum Pidana Dan Hukum Islam (Studi Perbandingan). Bachelor Thesis Criminal and Constitutional Law Department, UIN Alaudin Makassar. Retrieved from http://repositori.uin-alauddin.ac.id/6001/

Ulfa, L., Din, M., \& Dahlan, D. (2017). Penerapan Ajaran Turut Serta Kasus Korupsi Dikaitkan Teori Pertanggungjawaban Pidana. Kanun Jurnal Hukum, 19(2), 285304. 


\section{QUOTE}

\section{A man who has never gone to school may steal a freight car; but if he has a university education, he may steal the whole railroad}

\section{Theodore Roosevelt}

